\title{
Article
}

\section{Is keep/refer decision making an integral part of national guidelines for the physiotherapy profession within Europe? A review}

Lackenbauer, Wolfgang, Janssen, Jessie, Roddam, Hazel and Selfe, James

Available at http://clok.uclan.ac.uk/16586/

Lackenbauer, Wolfgang, Janssen, Jessie ORCID: 0000-0002-5961-2736, Roddam, Hazel ORCID: 0000-0002-0637-1801 and Selfe, James (2016) Is keep/refer decision making an integral part of national guidelines for the physiotherapy profession within Europe? A review. Physiotherapy . ISSN 00319406

It is advisable to refer to the publisher's version if you intend to cite from the work. http://dx.doi.org/10.1016/j.physio.2016.11.005

For more information about UCLan's research in this area go to http://www.uclan.ac.uk/researchgroups/ and search for < name of research Group>.

For information about Research generally at UCLan please go to http://www.uclan.ac.uk/research/

All outputs in CLoK are protected by Intellectual Property Rights law, including Copyright law. Copyright, IPR and Moral Rights for the works on this site are retained by the individual authors and/or other copyright owners. Terms and conditions for use of this material are defined in the policies page. 


\section{Accepted Manuscript}

Title: Is keep/refer decision making an integral part of national guidelines for the physiotherapy profession within Europe? A review

Author: Wolfgang Lackenbauer Jessie Janssen Hazel Roddam James Selfe

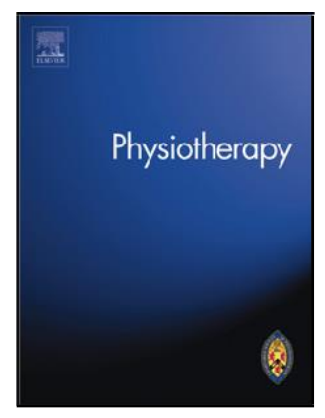

PII: S0031-9406(16)30490-4

DOI: http://dx.doi.org/doi:10.1016/j.physio.2016.11.005

Reference: PHYST 944

To appear in:

Physiotherapy

Please cite this article as: Lackenbauer Wolfgang, Janssen Jessie, Roddam Hazel, Selfe James.Is keep/refer decision making an integral part of national guidelines for the physiotherapy profession within Europe? A review.Physiotherapy http://dx.doi.org/10.1016/j.physio.2016.11.005

This is a PDF file of an unedited manuscript that has been accepted for publication. As a service to our customers we are providing this early version of the manuscript. The manuscript will undergo copyediting, typesetting, and review of the resulting proof before it is published in its final form. Please note that during the production process errors may be discovered which could affect the content, and all legal disclaimers that apply to the journal pertain. 
Is keep/refer decision making an integral part of national guidelines for the physiotherapy profession within Europe? A review.

\section{Corresponding author:}

Wolfgang Lackenbauer, MManpTh (Curtin).

wolfgang.lackenbauer@stu.mmu.ac.uk

00436508956022

Co-authors:

Jessie Janssen PhD, Research Fellow University of Central Lancashire/UK.

Hazel Roddam PhD, Principal Lecturer University of Central Lancashire/UK.

James Selfe DSc, Professor of Physiotherapy Manchester Metropolitan University/UK.

Keywords: Keep/refer decision making ability, physiotherapy, national competency guidelines. 


\begin{abstract}
Background: Keep/refer decision as the ability to independently determine whether a patient's condition is suitable for physiotherapy management (keep) or not (refer), is regarded as an core element in the World Confederation of Physical Therapists' (WCPT) Guideline for Standards of Physical Therapy Practice. However, it is currently unknown how individual European countries have implemented this in their national guidelines.
\end{abstract}

Objectives: To determine if keep/refer decision making abilities are an integral part of national guidelines for the physiotherapy profession of member countries of the European Network of Physiotherapy in Higher Education (ENPHE).

Data Sources: A review was performed including medical databases, the grey literature and personal correspondence with professional ENPHE member associations. To gain the information of interest, all eligible documents were reviewed.

Results: 11 national guidelines for the physiotherapy profession could be obtained. Two additional member associations use European guidelines as their national ones. Despite the fact that in the WCPT guidelines keep/refer decision making abilities are clearly described as a core element, there exists huge inconsistency as to how various European (with direct and non direct access systems) countries have included them in their national guidelines.

Conclusion: Despite the fact that most ENPHE member countries deem a close collaboration between health care professionals important and that physiotherapists should know the limitation of their expertise, keep/refer decision making abilities as explicitly stated in the WCPT guidelines were not included in the majority of guidelines that were reviewed. 
Keywords: Keep/refer decision making ability, physiotherapy, national competency guidelines.

\section{Introduction}

Patients can consult a physiotherapist in two ways: In a direct access system, patients can refer themselves to physiotherapeutic services without the need for prior examination by a medical professional. On the other hand, in a non direct access system, patients can consult a physiotherapist only after having seen a medical professional [1]. While proponents of a direct access system argue with the benefit of an overall reduction of health care costs $[1,2]$, opponents fear that physiotherapists might fail to recognise various significant (sometimes life threatening) medical pathologies with possible negative consequences for the patient's health [3]. However, independent from how patients have access to physiotherapy, the physiotherapist is required to independently examine the patient and make a decision on, whether or not the patient is suitable for physiotherapeutic management [4]. Despite the low prevalance of serious conditions affecting the neuro-musculoskeletal system [5], existing literature provides strong evidence that physiotherapists are capable of contributing to patient's safety by recognizing the presence of a wide range of systemic diseases and various pathologies which require (further) medical management [2, 3, 6] Goodman and Snyder [7] give sensible reasons, why all physiotherapists should be capable of making an independent and proper keep/refer decision:

“1) Clients may obtain a signed prescription for physical therapy based on similar past complaints of musculoskeletal symptoms without direct physician contact. 
2) Medical specialization: Medical specialists may fail to recognize underlying systemic disease.

3) Disease progression: Early signs and symptoms are difficult to recognize, or symptoms may not be present at the time of medical examination.

4) Patient/client disclosure: Client discloses information previously unknown or undisclosed to the physician.

5) Client does not report symptoms or concerns to the physician because of forgetfulness, fear, or embarrassment."

In a recent review, Boissonnault and Ross [6] extracted 78 published case reports and case series from the literature where multiple screening strategies performed by physiotherapists and subsequent referral for further medical evaluation finally led to the diagnosis of a wide range of different pathologies (such as metatstatic cancer, infection, spinal fracture, various visceral diseases) as underlying cause(s) of the patients ${ }^{6}$ complaints. Of those 78 cases, 58 patients $(74,4 \%)$ were examined by a medical professional before they were sent for physiotherapeutic management. Only a small proportion of patients consulted a physiotherapist without prior consultation of a medical professional [6]. This review highlights that the ability to autonomously decide (using proper screening strategies) whether a patient's condition is suitable for physiotherapeutic intervention (keep), or not (refer) is not solely important for physiotherapists who work in a direct access system, but for all physiotherapists [6].

With good reason, the WCPT Guidelines for Standards of Physical Therapy Practice [8] state that "where the examination, diagnostic process, or any change in status reveals findings outside the scope of knowledge, experience, and/or expertise of the physiotherapist, the 
patient/client shall be so informed and referred to the appropriate professional" [8]. Furthermore, the European Core Standards of Physiotherapy Practice [9] clearly demand that every physiotherapist should be capable of carrying out "a risk assessment prior to each treatment for every patient" [9]; and a close collaboration with other health professionals is desirable in order to provide effective patient management [9]. In this context, the European Core Standards of Physiotherapy Practice [9] directly refer to the WCPT Declaration of Principle [10] where it says that " when the diagnosis is not clear or the required intervention/treatment is beyond the capacity of the physical therapist, the physical therapist shall inform the patient/client and provide assistance to facilitate a referral to other qualified persons. Furthermore, the physical therapist will consult with the referring medical practitioner if the treatment programme or a continuation of the programme are not in accord with the judgement of the physical therapist". In addition, it is explicitly suggested that all member organisations should try to fulfill all aspects described in the standards in order to provide the physiotherapist with the knowledge necessary as "part of their professional responsibility" [8].

Despite the fact that the professional guidelines published by the WCPT $[8,10]$ and its European branch [9] clearly deem keep/refer decision making abilities to be important, it is not clear whether this is also reflected in individual national guidelines for the physiotherapy profession of various European countries that are also member associations of the European Network of Physiotherapy in Higher Education (ENPHE).

Therefore, a review was conducted in order to analyse if and in how far keep/refer decision making abilities are an integral part of all professional physiotherapy guidelines of ENPHE member associations. In addition, it was considered to be important if European countries with a direct access system to physiotherapy are more likely to have keep/refer decision 
making abilities included in their guidelines than European countries with a non direct access system where patients require a referral by a medical professional.

\section{Methods}

\section{$\underline{\text { Search }}$}

In order to collect national guidelines of ENPHE member countries, medical databases (Medline, Web of Science, CINHAL, Proquest and EMBASE) were initially searched using the terms "national guidelines", "standards of practice", "competency guidelines" or "professional profile". These terms were used in combination with either physiotherapy or physical therapy together with the country of interest. Furthermore, the grey literature (via Google, YAHOO and BING) was also searched using the same search terms. At the same time, 25 national physiotherapy associations of ENPHE member countries were contacted (via e-mail) [11] several times between 23/12/15 and 19/02/16 with a formal request to send us their national guidelines (preferably an English language version if one existed). If ,however, no English or German version was available, Google translater was used to translate the documents into English. An email to the European branch of the WCPT (ERWCPT) was sent to request if there existed a definitive European collection of the professional guidelines of all the individual European countries.

\section{$\underline{\text { Eligibility criteria }}$}

For our review, we targeted documents which serve as national guidelines for the physiotherapy profession of all 29 ENPHE member countries.

\section{Results of the search}

\section{Analysis of the documents}


A summary of the relevant passages of the individual documents can be found in Table 1. We looked for text passages that describe the physiotherapists' professional obligation to make an accurate and independent decision to either keep or refer a patient to a medical professional. If, however, keep/refer desicion making abilities were not explicitly mentioned, we also looked for text passages that demanded close collaboration with the referring medical/other health care professionals and/or feedback in the case of any unusal events that might occur during the examination and/or develop during the course of the therapy. In order to see whether a country has a direct or non direct access system to physiotherapy service, we used the information provided on the official homepage of the WCPT.

\section{Results of the literature search and return rate of personal correspondence}

No national guidelines for the physiotherapy profession were found in the medical databases. The grey literature was therefore searched and the national guidelines from the United Kingdom (UK) [12], Ireland [13], the Netherlands [14] and Austria [15, 16, 17] were found. Subsequently, an email was sent to the remaining 25 physiotherapy associations from ENPHE member countries and to the official email address as listed on the ER-WCPT website and answers were received from Belgium [18], Denmark [19], Germany [20], Italy [21], Lithuania [22], Norway [23], Switzerland [24], Slovenia [9], Malta, Sweden and the Czech Republic [25]. Sweden and Malta ,however, responded that they (currently) do not have national guidelines for the physiotherapy profession. Slovenia directly translated the ER-WCPT guidelines [9] into Slovenian and sent us the English version. The Czech Republic uses the European Physiotherapy Service Standards [25] and sent us the English document. The Norwegian physiotherapy association informed us that they do not have any professional guidelines. Instead, they sent us the' Framework for the Norwegian Physiotherapy Education [23] ' which we reviewed and included into our analysis. The national guidelines from 
Switzerland [24] refer to the 'Berufsordnung des Schweizer Physiotherapie Verbandes"

and its ethical guidlines for additional information. We therefore searched the grey literature und found the document which was subsequently included into our analysis. Unfortunately, we did not receive a response from the remaining 14 ENPHE member associations (Bulgaria, Croatia, Estonia, Finland, France, Greece, Iceland, Latvia, Lebanon, Montenegro, Poland, Portugal, Spain and Turkey). In addition, we did not receive a reply to our formal request to the ER-WCPT.

\section{$\underline{\text { Translation of the documents }}$}

Belgium, Italy, Denmark and Norway do not have an Englisch version of their guidelines. We therefore translated the documents using Google Translator. The national guidelines from Austria, Germany and Switzerland needed no translation since the lead author is from Austria and fluent in German.

\section{$\underline{\text { Results of individual guidelines }}$}

The results in Table 1 reveal that even among those countries that generally mention keep/refer decision making abilities in their national guidelines (Denmark, Belgium, the Netherlands, UK, Italy, Ireland), there is no clear consensus where the patient needs to be referred to or who should be consulted. Denmark, Belgium, the Netherlands, the United Kingdom and Italy use the more general term 'health care professional/provider' to where the patient shall be referred, whereas Germany and Switzerland (even though these two countries do not explicitly mention the keep/refer decision making process) require their physiotherapists to contact the referring medical professional. Ireland very clearly distinguishes between 'graduate entry level physiotherapists' and 'senior physiotherapists' or 
'clinical specialists'. Again, however, Ireland does not mention a medical professional who should be consulted but (only) talks about a 'higher level of authority'.

In the case of Austria, keep/refer decision making abilities do not appear to play a vital role in the ,Berufsprofil'. This document contains one paragraph that describes the physiotherapist's professional responsibility to determine if the referral by the medical professional is suitable from the perspective of the physiotherapy profession, or not [15]. It further says that this responsibility is especially important in the case of changes in the patient's health status [15], but a clear description of the keep/refer decision making process is missing. However, in a more recent paper describing the future role of physiotherapists as part of a primary health care system [17], physiotherapists are required to screen their patients whether there exists an indication for movement based intervention (physiotherapy), or not. Again, this document demands a close collaboration with other 'health care professionals' but there is no further definition on which health care professionals (medical professionals, psychologists, pharmacists) should be included in such a interdsciplinary collaboration.

Interestingly, even though it is undeniable that medical professionals have the appopriate educational background and diagnostic resources to, in the last instance, rule in/out serious medical conditions, only Germany [20] and Switzerland [26] very clearly mention that this specific professional group should be contacted. Others $[12,13,14,17,18,19,21]$ use more general terms such as 'health care providers', '(health care) professionals' or even 'higher level of authority‘. On the other hand, Germany and Switzerland do not directly require its physiotherapists to make an independent keep/refer decision but soley to contact the referring medical professional while countries such as Denmark, Belgium, the United Kingdom, the Netherlands, Italy and Ireland demand that the patient (if deemed necessary) be referred directly by the physiotherapist. 
Lithuania sent a document, which not only applies to the physiotherapy profession but is seen more as a guideline for professions that deal with rehabilitation in general including Physiotherapy, Occupational Therapy and Adapted Physical Activity [22]. This document does not specifically mention keep/refer decision making abilities but generally requires that the therapists should be able to make " an independent decision in a difficult situation that requires an innovative (holistic) approach" [22].

The biggest surprise were the results from the Scandinavian countries. Although Sweden is regarded as the homeland of the professional physiotherapy movement [27], the Swedish physiotherapy association informed us that they do not have any national guidelines for the physiotherapy profession. Norway does not have individual professional guidelines either. This was especially unexpected given the fact that Norway has a prestigious Manual Therapy Association [28] and with Freddy Kaltenborn a pioneer of Manual Therapy [29]. Instead, the Norwegian Physiotherapy Association sent us an 'Educational Framework' of what physiotherapy graduates are expected to learn during their undergraduate degree. This document mentions that the programme should be in "accordance with national and international guidelines“ but no further specification of what that exactly means could be found. For Finland, which has also a long tradition of physiotherapy education dating back to the end of the 19th century [30], it was unforturnatley impossible to obtain any guidelines. Only Denmark requires that physiotherapists should know the limitation of their own expertise and recognize the potential need of other health care providers [19]. The results from the Scandinavian countries were unexpected since in those countries, patients do not need (at least in the private sector) prior examination and referral from a medical professional [31].

$\underline{\text { Results in the context of the access system to physiotherapeutic service }}$ 
For countries that do not have a direct access system (Austria, Belgium, Germany, Switzerland) [31], the national guidelines of Belgium most specifically mention the keep/refer decision making process as a professional obligation for qualified physiotherapists. In the case of Austria, the 'Berufsbild' [15] does not explicitly mention keep/refer decision making abilities at all. It only requires the physiotherapists to determine if the referral is suitable from the perspective of the physiotherapy profession, or not [15]. Switzerland requires its physiotherapists to keep the referring medical professional up to date about the course of the treatment and the general outcome of the intervention [26], but keep/refer decision making abilities as an explicit requirement are missing.

In countries where patients can refer themselves to physiotherapy directly in the private sector but not in the public system [31] (Italy, Lithuania, Ireland, Denmark, Czech Republic, Slovenia, the Netherlands, Norway), only Italy, the Netherlands, Denmark and Ireland demand that physiotherapists must be able to decide about the appropriateness of physiotherapy for their patients. Slovenia has translated the ER-WCPT guidelines into Slovenian and therefore also requires its physiotherapists to be able make an accurate keep/refer decision.

In countries (UK) with direct access in both the public system and the private sector [31], it is mandatory that all qualified physiotherapists should have the professional autonomy to be able to determine when to keep or refer a patient.

In general, the regulatory requirement for professional autonomy over keep/refer decisions does not seem to correlate exclusively with the national health care system in each country. For instance, Belgium with no direct access system to physiotherapy [31] very clearly requires its qualified physiotherapists to know when to refer a patient [18]. In contrast, 
Norway with a direct access system at least for the private sector [31] does not mention keep/refer decision making attributes in its 'Educational Framework' at all [23].

\section{Discussion}

This review provides a unique insight into how individual ENPHE member associations include keep/refer decision making abilities into their national guidelines for the physiotherapy profession. This review also gives insight into the different interpretations of those specific abilites in individual national guidelines of ENPHE member associations. This is seems of significance in the light of recent changes within the European Mobility and Migration Policy [32] which make it easier for physiotherapists to have their qualifications recognized and subsequently allow them to work in different European Union member countries [33]. Given the fact that the keep/refer decision making process is a core element in the WCPT guidelines [8], the authors of this review believe that there exists no valid reason why this specific attribute, as part of the clinical reasoning process [34], should be omitted from the guidelines of some professional physiotherapy associations. Having said this, in the WCPT guidelines it is acknowleged that there is some room for interpretation based on individual national health care regulations [8]. However, the ability to make an independent keep/refer decision is certainly important for all physiotherapists to ensure patients` safety and should not depend on whether physiotherapists work in a direct or non direct access system $[6,7,35]$. Specific training in making keep/refer decisions and clinical triage has already shown to enable physiotherapsists who work in the United States Armed Forces to be highly effective in recognizing sinister conditions which require medical attention [36].

\section{Limitations}


There are two major limitations of this review that need to be mentioned. Firstly, and to our disapointment, it was not possible to obtain national guidelines from all ENPHE member organisations. Despite the fact that we contacted all ENPHE member associations several times via email, we did not receive an answer from all countries. In two cases (Sweden and Malta), we were notified that no national guidelines exist. As a consequence, it is impossible to get a complete European-wide overview of the importance of keep/refer decision making abilities as part of national guidelines. Secondly, only one country, whose first language is not English (the Netherlands) seems to have an English version of their guidelines. Lithuania also submitted a document which was in English. However, these were not the actual professional guidelines. When we requested the original Lithuanian guidelines so that we could translated them ourselves, we did not get a response back. For other countries (Belgium, Denmark, Norway, Italy) it was necessary to translate them into English using Google Translator. The fact that Google Translator, despite its usefulness and availability, is obviously not an officially acknowledged translator, there may be some translational mistakes/shortcomings. As a consequence, we have no certainty if we have either missed important passages that specifically mention keep/refer decision making abilities or our translation of the supposedly correct passage was not one-hundred percent correct. Since the main author is from Austria, there were no difficulties in ensuring an accurate translation of the German speaking guidelines (Austria, Switzerland, Germany). Slovenia directly translated the English version of ER-WCPT [9] guidelines into Slovenian and therefore caused no difficulty with the translation. The Czech Republic uses the European Physiotherapy Service Standards [25] which are also in English and required no further translation either.

\section{Conclusion}


This review is the first to assess whether keep/refer decision making abilities are specifically mentioned in the national guidelines of European countries which are also a member organisation of the ENPHE. Most surprisingly, not all ENPHE member countries seem to have yet developed individual national guidelines for the physiotherapy profession. Despite the fact that these specific abilities are undoubtedly an important part of the physiotherapeutic decision making process $[4,34]$, they are not explicitly mentioned in all national guidelines that we were able to review. Even though international guidelines $[8,9,10]$ clearly deem those abilities crucial for every physiotherapist and the literature is full of case reports where physiotherapists helped to detect a wide range of systemic pathologies [6], those abilities are not included as a specific requirement in all guidelines that we were able to review. Despite the clear description of those abilities in the WCPT guidelines [8] (which are prescriptive and leave no room for interpretation), most countries have made some amendments for their own guidelines.

\section{Recommendations}

Future research should concentrate on analysing in how far qualified physiotherapists and physiotherapy students (in both, direct and non direct access system) across Europe are capable of making an accurate keep/refer decision as part of their clinical reasoning process. There have been some studies on qualified physiotherapists in Germany [37] and Switzerland [38]; data from other European countries is currently missing. In addition, it is the authors ${ }^{\text {‘ }}$ opinion that there should be a European wide consensus about keep/refer decision making abilities as a mandatory content of all national guidelines (regardless of whether there exists a direct or non direct access system to physiotherapy). Moreover and most importantly, these specific abilities should be a compulsory part of every undergraduate physiotherapy curriculum across all European Universities. 


\section{Funding}

No financial support was received for the preparation of this manuscript.

\section{Conflict of interest}

None.

\section{References}

[1] Ojha HA, Snyder RS, Davenport TE. Direct access compared with referred physical therapy episodes of care: a systematic review. Phys Ther 2014;94 (1):14-30.

[2] Desmeules F, Roy JS, MacDermid JC, et al. Advanced practice physiotherapy in patients with musculoskeletal disorders: a systematic review. BMC musculoskeletal disorders, 2012, 13:107 doi:10.1186/1471-2474-13-107

[3] Deyle GD. Direct Access Physical Therapy and Diagnostic Responsibility: The Risk-To-Benefit Ratio. J Orthop Sports Phys Ther 2006;36(9):632-4. doi:10.2519/jospt.2006.0110.

[4] Boissonnault WG, Bass C. Medical Screening Examination: Not Optional for Physical Therapists. J Orthop Sports Phys Ther 1991;14:241-2.

[5] Verhagen AP, Downie A, Popal N, Maher C, Koes BW. Red flags presented in current low back pain guidelines: a review. Eur Spine J 2016 DOI 10.1007/s00586016-4684-0.

[6] Boissonnault WG, Bass C. Physical therapists referring patients to physicians: a review of case reports and series. J Orthop Sports Phys Ther 2012;42:446-54.

[7] Goodman CC, Snyder TEK. Differntial Diagnosis for Physical Therapists. Screening for Referral. 5th ed. St. Louis, Missouri: Saunders Elsevier; 2013. 
[8] WCPT guideline for standards of physical therapy practice. London (UK), http://www.wcpt.org/ (2011, accessed 08 February 2016).

[9] European Core Standards of Physiotherapie Practice. Brussels (BE), http://www.erwcpt.eu/physiotherapy_and_practice/tools_and_resources $(2008$, accessed 11 November 2014).

[10] WCPT Declaration of Principle: Ethical Prinicples. London (UK), http://www.wcpt.org/sites/wcpt.org/files/files/WCPT-DoP-Ethical_PrinciplesAug07.pdf (2007, accessed 10 February 2016).

[11] European Network of Physiotherapy in Higher Education. Enschede (NL), http://enphe.org/Network.aspx (2016, accessed 18 March 2016).

[12] Health and Care Professions Council. Standards of proficiency - Physiotherapists (UK), $\quad$ http://www.hpc-uk.org/publications/standards/index.asp?id=49. accessed 22 December 2015).

[13] Therapy Project Office HSE Physiotherapy Competencies (IE), http://www.iscp.ie/therapy-project-office-hse-physiotherapy-competencies-2008. (2008, accessed 15 December 2015).

[14] The professional profile of the physical therapist (NL), http://www.srof.nl/images/Downloads/0009\%20beroepsprofiel\%20eng.lr.pdf $\quad$ (2006, accessed 01 February 2016).

[15] Berufsprofil des/der diplomierten Physiotherapeutin/Physiotherapeuten (AT), https://www.physioaustria.at/system/files/general/berufsprofil.pdf (2004, accessed 10 February 2016). https://www.ris.bka.gv.at/GeltendeFassung.wxe?Abfrage=Bundesnormen\&Gesetzesn $\underline{\text { ummer }=20004516}$. $(2006$, accessed 07 February 2016). 
[17] PhysiotherapeutInnen in Primary Health Care- best point of service (AT), https://www.physioaustria.at/system/files/general/positionspapier_physiotherapeutinne n_in_phc_062014.pdf (2014, accessed 10 February 2016).

[18] Beroeps- en Competentieprofiel van de kinesitherapeut in België (BE) 2010.

[19] Etiske retningslinjer for Danske (DK).

[20] Deutscher Verband für Physiotherapie (ZVK) E.V. Berufsordung (DE) .

[21] La Formazione "Core“ del Fisoterapista (IT) 2013.

[22] Descriptor of the study field of Rehabilitation (LT) 2015.

[23] Rammeplan for Fysioterapeututdanning (NO) 2004.

[24] Berufsbild Physiotherapie (CH) 2009.

[25] European Physiotherapy Service Standards. Brussels (BE), http://www.erwcpt.eu/physiotherapy_and_practice/tools_and_resources.

$(2003$, accessed 11 February 2016).

[26] Berufsordnung des Schweizer Physiotherapie Verbandes. Sursee (CH), http://www.physioswiss.ch/download/online/090327_d_Berufsordnung_1.pdf. (2013, accessed 15 March 2016).

[27] Ottosson A. The First Historical Movements of Kinesiology: Scientification of Borderline between Physical Culture and Medicine around 1850. Int $\mathbf{J}$ Hist Sport. 2010;27(11):1892-1919. doi: 10.1080/09523367.2010.491618.

[28] Knipp R. First Contact Practice für PhysiotherapeutInnen. Eine weitere berufspolitische Entwicklung und ein Muss für die Zukunft? Eine Online Umfrage und Analyse unter PhysiotherapeutInnen in Österreich [Master Thesis]. Danube University Krems; 2008.

[29] The International Federation of Orthopaedic Manipulative Physical Therapists (IFOMPT). Historical Perspective, 
http://www.ifompt.org/ReportsDocuments/IFOMPT+Educational+Standards+A+Hist orical+Perspective.html. (2015, accessed 01 March 2016).

[30] Finnish Association of Physiotherapists (FAP). Physiotherapy education in

Finland, http://suomenfysioterapeutit.fi/index.php/education (2012, accessed 02 March 2016).

[31] World Conferderation of Physical Therapy. London (UK), http://www.wcpt.org/regions (2016, accessed 11 February 2016).

[32] World Conferderation of Physical Therapy: European Region. Brussels (BE), http://www.erwcpt.eu/physiotherapy_and_practice/mobility_and_migration_informati on. (2016, accessed 04 March 2016).

[33] The European Commission. Single Markets and Standards: European Professional Card, http://ec.europa.eu/growth/single-market/services/free-movementprofessionals/policy/european-professional-card/index_en.htm (2016, accessed 04 March 2016).

[34] Jones MA. Clinical Reasoning in Manual Therapy. Phys Ther 1992;72:875-84.

[35] Davenport TE, Sebelski CA. The Physical Therapists as a Diagnostician: How Do We, Should We, and Could We Use Information About Pathology in Our Practice? Phys Ther 2011;91:1694-5.

[36] Moore JH, McMillian DJ, Rosenthal MD, Weishaar MD. Risk Determination for Patients With Direct Access to Physical Therapy in Miltary Health Care Facilities. J Orthop Sports Phys Ther 2005;35:674-8.

[37] Beyerlein C. Direktzugang in der Physiotherapie-Wie entscheiden sich Physiotherapeuten im Management ihrer Patienten? PhD Thesis, Universitätsklinikum Ulm (DE), 2010.

[38] Direktzugang zur Physiotherapie in der Schweiz, http://www.physioswiss.ch/download/online/110930_Unternehmerforum_farbig.pdf. (2011, accessed 13 March 2016). 
Table 1. Profile of various European countries concerning direct access to physiotherapy. 


\begin{tabular}{|c|c|c|c|c|c|c|c|}
\hline $\begin{array}{l}\text { ENPHE } \\
\text { Member } \\
\text { Association }\end{array}$ & $\begin{array}{l}\text { Professional } \\
\text { Guideline (Original } \\
\text { Title) }\end{array}$ & Relevant Keep/Refer statement (English translation) & $\begin{array}{l}\text { Guideline } \\
\text { date }\end{array}$ & $\begin{array}{l}\text { Native } \\
\text { language } \\
\text { version } \\
\text { (YES/N } \\
\text { O) }\end{array}$ & $\begin{array}{l}\text { Direct } \\
\text { translation of } \\
\text { ER-WCPT } \\
\text { guideline } \\
\text { (YES/NO) }\end{array}$ & $\begin{array}{l}\text { Direct access to } \\
\text { physiotherapy } \\
\text { (YES/NO) }\end{array}$ & $\begin{array}{lr}\begin{array}{l}\text { Differentiated } \\
\text { regulations }\end{array} & \text { for } \\
\text { generalist } & \text { versus } \\
\text { specialist } & \text { grades } \\
\text { (YES/NO) } & \end{array}$ \\
\hline Denmark & $\begin{array}{l}\text { Etiske retningslinjer } \\
\text { for } \quad \text { Danske } \\
\text { Fysioterapeuter }\end{array}$ & $\begin{array}{l}\text { Physiotherapists refer patients to colleagues or other health } \\
\text { professionals when the limit of own area of competence has } \\
\text { been reached and it is estimated that other competencies are } \\
\text { necessary to ensure optimal patient care. (p.5) }\end{array}$ & Unkown & YES & NO & $\begin{array}{l}\text { YES ( but only } \\
\text { for the private } \\
\text { sector) }\end{array}$ & NO \\
\hline Norway & $\begin{array}{l}\text { RAMMEPLAN } \\
\text { FOR } \\
\text { FYSIOTERAPEUTU } \\
\text { TDANNING }\end{array}$ & $\begin{array}{l}\text { Physiotherapist program shall be in accordance with national } \\
\text { and international health } \\
\text { education policy guidelines (p.4). }\end{array}$ & 2004 & YES & NO & $\begin{array}{l}\text { YES ( but only } \\
\text { for the private } \\
\text { sector) }\end{array}$ & NO \\
\hline Lithuania & $\begin{array}{l}\text { Descriptor of the } \\
\text { study field of } \\
\text { Rehabilitation }\end{array}$ & $\begin{array}{l}\text { Take an independent decision in a difficult situation that } \\
\text { requires innovative (holistic) approach (17.4.2.) }\end{array}$ & 2015 & YES & NO & $\begin{array}{l}\text { YES ( but only } \\
\text { for the private } \\
\text { sector) }\end{array}$ & NO \\
\hline Belgium & $\begin{array}{l}\text { Beroeps- en } \\
\text { Competentieprofiel } \\
\text { van de } \\
\text { kinesitherapeut } \\
\text { in België }\end{array}$ & $\begin{array}{l}\text { Depending on the results of the first screening } \\
\text { and taking the findings in the clinical examination the } \\
\text { physiotherapist, in consultation with the patient, decides to set } \\
\text { in treatment, give the necessary advice or refer to another } \\
\text { health care provider. (p.18) }\end{array}$ & 2010 & YES & NO & NO & NO \\
\hline Germany & $\begin{array}{l}\text { Berufsordnung des } \\
\text { deutschen Verbandes } \\
\text { für Physiotherapie }\end{array}$ & $\begin{array}{l}\text { If any pecularities during the examination or the course of the } \\
\text { treatment occur, consult with the referring medical practicioner } \\
\text { if deemed necessary (p.2). }\end{array}$ & Unkown & YES & NO & NO & NO \\
\hline Ireland & $\begin{array}{l}\text { Therapy Project } \\
\text { Office; Physiotherapy } \\
\text { Competencies }\end{array}$ & $\begin{array}{l}\text { Graduate Entry level: } \\
\text { "Recognizing own limitations and liaising with senior staff and } \\
\text { other team members when appropriate." (p. 11) } \\
\text { Senior competencies and Clinical Specialist: } \\
\text { "Recognizing when it is appropriate to refer decisions to a } \\
\text { higher level of authority and include colleagues in the decision } \\
\text { making process." (p. } 13 \text { and p. } 16)\end{array}$ & 2008 & YES & NO & $\begin{array}{l}\text { YES ( but only } \\
\text { for the private } \\
\text { sector) }\end{array}$ & YES \\
\hline $\begin{array}{l}\text { The } \\
\text { Netherlands }\end{array}$ & $\begin{array}{l}\text { The professional } \\
\text { profile of the physical } \\
\text { therapist }\end{array}$ & $\begin{array}{l}\text { Depending on the results of the first screening and the } \\
\text { findings from the physiotherapeutic evaluation, the physical } \\
\text { therapist makes decision in consultation with the } \\
\text { patient with regard to the treatment to be started, advice or } \\
\text { referral." In direct access, the physical therapist determines in } \\
\text { the first screening whether further physiotherapeutic }\end{array}$ & 2006 & NO & NO & $\begin{array}{l}\text { YES ( but only } \\
\text { for the private } \\
\text { sector) }\end{array}$ & NO \\
\hline
\end{tabular}




\begin{tabular}{|c|c|c|c|c|c|c|c|}
\hline & & $\begin{array}{l}\text { analysis is useful. Depending on the outcomes, diagnostic } \\
\text { physiotherapeutic evaluation is subsequently done } \\
\text { or the patient is referred." (p.17) }\end{array}$ & & & & & \\
\hline Austria & $\begin{array}{l}\text { Berufsbild } \\
\text { Physiotherapie. } \\
\text { MTD } \\
\text { Ausbildungsverordnu } \\
\text { ng. } \\
\text { PhysiotherapeutInnen } \\
\text { in Primary Health } \\
\text { Care- best point of } \\
\text { service. }\end{array}$ & $\begin{array}{l}\text { Primary Health Care: } \\
\text { Communication with other health care providers. } \\
\text { Screening what kind of or whether movement based } \\
\text { intervention is indicated. } \\
\text { MTD Ausbildungsverordnung: } \\
\text { 4. Recognize authority/competence of other medical/health care } \\
\text { professions. } \\
\text { Berufsbild: } \\
\text { Independently assess if referral by medical practicioner is } \\
\text { suitable from the perspective of the physiotherapy profession (p. } \\
\text { 20); Especially important in the event of changes in the patient's } \\
\text { health status (p.21). }\end{array}$ & $\begin{array}{l}2004 \\
2006 \\
2014\end{array}$ & $\begin{array}{l}\text { YES } \\
\text { YES } \\
\text { YES }\end{array}$ & NO & NO & NO \\
\hline $\begin{array}{l}\text { United } \\
\text { Kingdom }\end{array}$ & $\begin{array}{l}\text { Standards of } \\
\text { Proficiency }\end{array}$ & $\begin{array}{l}\text { "Registrant physiotherapists must know the limits of their } \\
\text { practice and when to seek advice or refer } \\
\text { to another professional." (p. } 7 \text { ) }\end{array}$ & 2013 & YES & NO & YES & NO \\
\hline Italy & $\begin{array}{l}\text { LA FORMAZIONE } \\
\text { “CORE” DEL } \\
\text { FISIOTERAPISTA }\end{array}$ & $\begin{array}{l}\text { Refer the patient to another (health care) professional when } \\
\text { their activity is required and when the situation is beyond the } \\
\text { therapists professional and / or experience and/or competence } \\
\text { (page. 72). }\end{array}$ & 2013 & YES & NO & $\begin{array}{l}\text { YES ( but only } \\
\text { for the private } \\
\text { sector) }\end{array}$ & NO \\
\hline Slovenia & $\begin{array}{lr}\text { European } & \text { Core } \\
\text { Standards } & \text { of } \\
\text { physiotherapy } & \\
\text { practice (Slovenian } \\
\text { translation) }\end{array}$ & Refer to original document & 2008 & No & Yes & $\begin{array}{l}\text { YES (but only for } \\
\text { the private sector) }\end{array}$ & No \\
\hline Switzerland & $\begin{array}{ll}\text { Berufsbild } & \\
\text { Physiotherapie. } & \\
\text { Berufsordnung des } \\
\text { Schweizer } \\
\text { Physiotherapie } \\
\text { Verbandes }\end{array}$ & $\begin{array}{l}\text { Berufsordnung des Schweizer Verbandes: } \\
\text { Inform referring doctor about course of the treatment and } \\
\text { treatment outcome (p. 3). } \\
\text { Promote interdisciplinary collaboration within various health } \\
\text { professions (p. 3). }\end{array}$ & $\begin{array}{l}2009 \\
2013\end{array}$ & Yes & NO & NO & NO \\
\hline $\begin{array}{l}\text { Czech } \\
\text { Republic }\end{array}$ & $\begin{array}{l}\text { European } \\
\text { Physiotherapy } \\
\text { Service Standards }\end{array}$ & I & 2003 & NO & YES & $\begin{array}{l}\text { YES ( but only } \\
\text { for the private } \\
\text { sector) }\end{array}$ & NO \\
\hline
\end{tabular}

